\title{
President Trump and the Mother of All Bombs - Quickly Forgotten
}

\author{
By Judith Sylvester ${ }^{*}$
}

When the United States military dropped the GBU-43/B Massive Ordnance Air Blast (MOAB) in Nangarhar Province in Afghanistan in April 2017 both the news media and social media also blew up - but only for a couple of weeks. Nicknamed the "Mother of All Bombs, "MOAB is the largest non-nuclear bomb ever dropped in combat. It literally came out of the blue, shocking not only the tunnels in Afghanistan it was meant to destroy, but briefly the entire world. Donald Trump was in his first 100 days as president of the United States. Because President Trump took no credit for the decision to drop MOAB, whether the action was taken for military or political purposes remains an open question. International media were more graphic in their description of the bomb's destruction and provided more reactions from Afghan leaders. As many as 95 ISIS fighters were reported killed, with no civilians reported killed. US media that support President Trump reported the use of MOAB in more patriotic terms than less supportive media. A Crimson Hexagon software analysis of social media posts reveal that "fear" was the overwhelming emotion expressed. Twitter was the No. 1 source of comments. International sources were more likely than American sources to predict that a new, non-nuclear weapons race among major world military powers, would result.

Keywords: Afghanistan, bomb, Massive Ordnance Air Blast, Trump

\section{Introduction}

When the United States military dropped the GBU-43/B Massive Ordnance Air Blast (MOAB) in Nangarhar Province in Afghanistan on April 13, 2017, both the news media and social media also blew up. Nicknamed the Mother of All Bombs, this was the largest non-nuclear bomb ever dropped. It literally came out of the blue, shocking not only the tunnels in Afghanistan it was meant to destroy, but the entire world - at least for a couple of weeks.

The purpose of this study was to gauge world-wide reaction to the decision to drop MOAB during Donald Trump's early days as president and to see whether the United States would face unexpected consequences in the form of a new non-nuclear arms race.

To evaluate world reaction to the deployment of a bomb that was second only to a nuclear bomb in destructive power, social media posts and reposts (the majority from Twitter) were tracked. English language news articles were pulled from a large database of newspapers and broadcast transcripts. Additional articles were captured from media and military websites. Descriptions of the bomb were pulled from US military internet home pages and press releases.

The MOAB was not well known outside military circles. Developed during the Iraq War but never used, the weapon had faded from memory. The term "Mother of all...came into the American consciousness when Saddam Hussein

\footnotetext{
*Associate Professor, Manship School of Mass Communication, Louisiana State University, USA.
} 
referred to the Gulf War as the "mother of all battles." He actually used an Arabic phrase that more closely means "locked in battle" but the Associated Press translated it differently and the rest is history (Abadi, 2017).

In 2001, the US military was in Afghanistan, trying to find Osama Bin Laden in the Tora Bora Mountains and destroy his stronghold. The 15,000 BLU-82 Daisy Cutter bombs were used to shock the mountains, but Bin Laden escaped into Pakistan (Corera, 2011). During the Obama administration, drone warfare was expanded. However, because civilians, and even American citizens who had become "enemy combatants," were killed along with the targeted terrorists, the expanded use of drones was termed "a shameful part" of Obama's legacy by the Washington Post (Downie, 2016).

Because the US military has been fighting in Afghanistan since 2001 without either a military or diplomatic solution, deploying MOAB may have been viewed as inevitable as the US military tried again to crush the life out of ISIS fighters hiding in the mountains of Nangarhar Province.

\section{Literature Review}

\section{What is GBU-43/B?}

GBU-43/B (MOAB) was dropped on April 13, 2017. The news media covering the event scrambled to find out what this bomb was all about. Social media also became a microcosm of public shock and opinion. In some quarters, people expressed pride that the US had demonstrated such military power, but many others expressed sorrow and fear that a new arms race was now likely.

MOAB was not a recent invention. It was first prototyped in 2003 when the United States was engaged in the Iraq War. Unlike most such weapons, this bomb was created in-house at the Air Force Research Laboratory Munitions Directorate housed at Elgin Air Force Base in Florida. Albert L. Weimorts, who died in 2005, was a civilian engineer for the Air Force who conceived and designed some of the biggest, most powerful non-nuclear bombs ever made (Zachary, 2008). An additional contributor to the MOAB's design was Henry I. Register who died in 2007. He spent 52 years working on Eglin Air Force Base and was a manger for the MOAB project (Team, 2008).

The lead model maker was Joseph Fellenz who retired from the Eglin Air Force Base weapons lab in 2008. According to an interview in USA Today, Fellenz was surprised to learn from television news that the bomb had been used (Gabriel, 2017).

MOAB was designed as the largest-ever satellite-guided (or "smart bomb") air-delivered weapon, replacing the 15,000 BLU-82 Daisy Cutter that was used in Vietnam and early on in Afghanistan (Collins, 2017). The order came to build it during Thanksgiving 2002. "We were asked to generate a prototype, and we were asked to work out the bugs so that it might evolve into something that could be produced (for the warfighter)," said Robert Hammack, Munitions Fabrication Facility (or Model Factory) team chief (Zachary, 2008). 
Produced during the Iraq War era, "The goal is to have the pressure be so great that Saddam Hussein cooperates," said then Defense Secretary Donald Rumsfeld in a March 2003 interview. "Short of that - an unwillingness to cooperate - the goal is to have the capabilities of the coalition so clear and so obvious that there is an enormous disincentive for the Iraqi military to fight against the coalition" (Collins, 2017).

Unlike any project before or since, the model shop was solely responsible for coordinating the logistics on material acquisition and engineering. MOAB was designed, built, tested and refined entirely on location. After each weapon was assembled, it was individually loaded onto a rented flatbed truck, secured and covered by tarps. The munition was then transported to the Naval Ammunition Depot at McAllister, Okla., where it was filled with explosive materials, painted and catalogued for the inventory. MOAB was painted a "John Deere green" since no other color was available because of the war (Gabriel, 2017).

None of the military sources have revealed how many MOABs have been manufactured, but European sources have estimated that as many as 20 could be in the US arsenal. In 2017 only one was required.

\section{How the Bomb Works}

MOAB has an explosive force equal to 11 tons of TNT. Weighing more than 21,000 lbs., the weapon is the largest non-nuclear bomb ever used in combat. CBS News national security correspondent David Martin reported that the bomb was aimed at the center of an ISIS cave complex in Afghanistan and set off a "massive pressure cave that would have crushed the life out of any fighters hiding in the cave," sending a mushroom-like cloud into the sky (CBS Interactive, Inc., 2017).

An "official" description of the bomb and an aerial photo of the impact were provided by the Department of Defense (DoD) the day after the drop. The report said MOAB was developed in only nine weeks in 2003 to be available for Operation Iraqi Freedom. The bomb was not used during that war (Collins, 2017).

The DoD also provided the basic specs for the bomb:

- It has a relatively thin aluminum casing designed to burst on a surface, not penetrate it. That creates a large blast with lesser fragmentation.

- It is a "smart bomb" with GPS-guided munition. It has got stabilizing fins and inertial gyro for pitch and roll control.

- It weighs 21,000 pounds!

- The MOAB delivers an 18,700-pound warhead known as the BLU-120/B, which is made of $\mathrm{H6}$ - a mixture of cyclotrimethylene trinitramine, TNT and aluminum.

- It is big - 30 feet long with a diameter of 40.5 inches, to be exact (Collins, 2017).

The MOAB has a rather low-tech launching system. It is cradled on an airdrop platform of a C1-30 Hercules. A drogue parachute (designed by a Russian in 1912) 
pulls the entire platform off the plane at a high altitude and slows the descent. It is quickly released from the platform, and grid fins open to stabilize and guide it to its target (Collins, 2017).

\section{News Media Coverage}

The United Kingdom's Daily Mail provided a detailed and graphic description of what happens when the bomb reaches its target:

In the milliseconds following the initial blast in Afghanistan, all the oxygen would have been sucked out of the tunnels and for hundreds of feet around, literally sucking the life out of ISIS terrorists, suffocating them as their lungs imploded. Then, in a flash the fiery shockwave would have blasted outwards at the speed of sound for up to a mile, causing huge blunt force trauma injuries to anyone caught in its path, leveling buildings and trees.

Ears would have been left bleeding and internal organs battered by the sheer force of the shockwave. The blast would also have caused many within two miles of the blast to lose their hearing. Anyone caught inside the tunnels would have been crushed as the force of 19,000 pounds of highly complex explosives caused them to collapse on top of the ISIS terrorists. Anyone left alive would have been shocked and left in awe by the sight of a terrifying mushroom cloud - the psychological scars staying with them forever (DAILYMAIL.COM REPORTER, 2017).

The Guardian, another British newspaper, interviewed an Afghan, Mohammad Shahzadah, who lives in Shaddle Bazar, about a mile and a half from an area called Asadkhel and the mountains were the bomb exploded. "The earth felt like a boat in a storm," Shahzadah said. "I thought my house was being bombed. Last year a drone strike targeted a house next to mine, but this time it felt like the heavens were falling. The children and women were very scared. My ears were deaf for a while. My windows and doors are broken. There are cracks in the walls." The sky was engulfed in flames, and tremors shook the ground (Rasmussen, 2017). (Photos of MOAB and the blast appear in Appendix A.)

Perhaps to drive home the point that this is an American bomb, The Daily Mail further described what would happen if the bomb exploded six feet over New York City: At "ground zero" complete destruction and 100 percent fatalities. Buildings in a radius of 300-feet away would be severely damaged. People up to 430-feet away would suffer 3rd degree burns, and some would suffer the loss of limbs (DAILYMAIL.COM REPORTER, 2017).

The Associated Press (AP) and The New York Times often set the agenda for much of the US news media. Both were decidedly brief and much less descriptive in their coverage. The AP distributed a photo of MOAB with a description of its 11 tons of explosives. The story, however, focused on the authorized use of the bomb:

The US commander in Afghanistan who ordered use of the "mother of all bombs" to attack an Islamic State stronghold did not need President Donald Trump's approval, Pentagon officials said Friday. 
The officials said Gen. John Nicholson has standing authority to use the bomb, which is officially called the Massive Ordnance Air Blast bomb, or MOAB, the largest non-nuclear bomb ever dropped in combat. The bomb had been in Afghanistan since January.

The officials were not authorized to speak publicly on the matter and requested anonymity (Burns, 2017).

The New York Times, the newspaper that often sets the media agenda, only published four news summaries and one Op-ed about the bomb. Additionally, video footage showed the bomb dropping and the aftermath with some background narrative providing history and context. Except for the Op-ed, the stories mostly provided the facts and were reported by a Washington reporter and three reporters stationed in Afghanistan:

The United States dropped the "mother of all bombs" - the most powerful conventional bomb in the American arsenal - on an Islamic State cave complex in Afghanistan on Thursday, the Pentagon said, unleashing a weapon so massive that it had to be dropped from the rear of a cargo plane.

The strike was the first combat use of what is formally named the GBU-43/B Massive Ordnance Air Blast. President Trump has bestowed additional authority on the Pentagon in his first months in office, which the military has argued will help it defeat the Islamic State more speedily. Mr. Trump did not say whether he had personally approved Thursday's mission (Cooper \& Marshal, 2017).

The Op-ed was written by Ali M. Latifi, a writer based in Kabul, Afghanistan, for the Times' international edition. He struck a decidedly different tone in expressing his reaction to the "Madar-e Bamb-Ha," as the Afghans called it. He first summarized a history of nearly 40 years of war in his country. He described how he heard about the bomb and then his drive to the area where the bomb exploded. He wrote:

Hillary Clinton and Donald Trump barely mentioned Afghanistan during the long presidential campaign. Yet President Trump had chosen to use the most powerful non-nuclear weapon in the world on a remote Afghan village. Afghanistan was simply a convenient landscape for the reality star turned president to unleash a startling, theatrical display of his might...

I went to bed that night sad with the knowledge that my homeland was still simply a staging ground for foreign nations to project their power. On Friday morning I woke up to find Kabul had chosen to stay quiet and not protest the decision...

In the end, "Madar-e Bamb-Ha" became the star of a grotesque reality television show. We know how much it weighs, what it costs, its impact, its model number and its code name. We know nothing about the people it killed except they are supposed to be nameless, faceless, cave-dwelling Islamic State fighters. It was a loud blast, followed by a loud silence. It is yet another bomb to fall on Afghan soil, and the future of my homeland remains as uncertain as ever (Latifi, 2017). 
American media that have supported President Trump were the most elated by the MOAB deployment. A Fox News host said that dropping a massive bomb on ISIS fighters in Afghanistan is "what freedom looks like." The remark came after Fox began the segment of "Fox and Friends" with a clip of the "mother of all bombs" being dropped - set to the music of Toby Keith's "Courtesy of the Red, White, and Blue." Fox correspondent-at-large Geraldo Rivera said, "It's one of my favorite things to watch" (Szoldra, 2017).

The New York Daily News used the headline: ISIS, HAVE A BLAST! The article pointed out that Trump was still in his first 100 days as president: "He promised that, if elected, he would 'knock the hell out of' ISIS" (Silverstein \& Dillon, 2017).

\section{The Politics}

A matter of speculation is who authorized MOAB's deployment and whether it was used for military or political purposes. Did President Trump authorize it? He never took direct responsibility for it. During a White House meeting on the afternoon of the day the bomb was dropped, this exchange took place:

SHOUTED QUESTION: How about that bomb, sir? Did you authorize that bomb? PRESIDENT TRUMP: I'm very, very proud of the people. Really another successful job. We're very, very proud of our military. Just like we're proud of the folks in this room, we are so proud of our military, and it was another successful event.

REPORTER: Did you authorize it?

TRUMP: Everyone knows exactly what happened. So, and, what I do is I authorize my military. We have the greatest military in the world, and they have done the job, as usual. We have given them total authorization, and that's what they're doing, and frankly, that's why they've been so successful lately. Take a look at what's happened over the last eight weeks and compare it with the last eight years. There is a tremendous difference. Tremendous difference. We have incredible leaders in the military, and incredible military, and we are very proud of them.

REPORTER: Does this send a message to North Korea?

TRUMP: I don't know if this sends a message, it doesn't make any difference if it does or not. North Korea is a problem, the problem will be taken care of. I will say this. I think China has really been working very hard. I have really gotten to like and respect President $\mathrm{Xi}$. He is a terrific person, we've spent a lot of time together in Florida, and he is a very special man. We'll see how he does. I think he is going to try very hard (Hains, 2017).

President Trump's reluctance to claim personal credit led several news organizations, including the Associated Press, to give the US commander in Afghanistan the credit for ordering the use of MOAB. The Associated Press went so far as to say that Gen. John Nicholson had standing authority to use the bomb even before Trump took office in January 2017 (The Associated Press, 2017).

The Associated Press further challenged views that the bomb was dropped to terrorize North Korea and other US enemies. The actual "military" reasons for dropping the bomb were: 
1) To destroy a tunnel and cave complex used by Islamic State fighters in a remote mountainous area of eastern Afghanistan.

2) Nicholson wanted to demonstrate to leaders of the Islamic State affiliate in Afghanistan the seriousness of his determination to eliminate the group as a military threat (The Associated Press, 2017).

Initial reports indicated that 36 ISIS fighters were killed in the collapsed tunnels. However, later Afghan reports placed the number at 95 with no civilian casualties. An expert in MOAB and the Daisy Cutter, retired US Air Force Col. Dave Lewis, who currently is the director of strategic studies graduate program at Texas Tech University, said, "The use of the GBU-43/B is intended to send a strong message to adversaries and potential adversaries that the United States is willing to commit significant technology and resources to counter an enemy's unconventional tactics." He further pointed out that the reported target for MOAB was insurgents hiding in caves in Afghanistan, an area where noncombatant civilians were unlikely to be (Young, 2017).

Afghan leaders were divided in their views. Former President Hamid Karzai accused the United States of using his country as a weapons testing ground. He described it as an "immense atrocity against the Afghan people" and that Afghanistan "was used very disrespectfully by the United States to test its weapons of mass destruction" (Robinson, 2017).

Timor Sharan, senior analyst at the International Crisis Group in Washington, called the attack "disproportionate." "It's more about the message than the act sending a clear message to regional players, including Russia and as far as North Korea, to say that the United State is ready to take action and utilize necessary force," he said.

Abdula Abdula, chief executive of the Islamic Republic of Afghanistan, on the other hand, praised the action, saying that many key terrorists were killed, and the majority of Afghans supported the action. "People kept saying no serious intention is given to fighting against Daesh (ISIS), Al Qaeda and the Taliban but now their trust has been restored about the seriousness for the will to fight terrorism," he said (Hamdard, 2017).

Local tribal leaders also publicly supported the attack because they said it was successful without civilian casualties. They said that Daesh was a huge threat to the people in Nangarhar Province and that they were relieved that the terrorists were killed off with one bomb (McLaughlin, 2017). Some Afghan officials who would not go on the record complained about a lack of information about the effects of the bomb, saying they had not been allowed to go to the site.

Some news organizations that covered the war in Afghanistan claim that the US military had broadcast radio messages warning of coming operations by American and Afghan troops in southern Nangarhar for at least a month before the strike. Leaflets also were dropped warning residents to leave as soon as possible "to save their lives." Because of fighting that was occurring in the area, many people in nearby villages had already left (McLaughlin, 2017).

Adding to the debate, some commentators pointed to the timing to suggest that President Trump was making a foreign policy statement. The MOAB strike 
came the same day the Pentagon admitted that an American-led air strike mistakenly killed 18 Syrian fighters allied with the United States in Syria. Also, the Afghanistan attack occurred days after Syrian President Bashar al-Assad launched a chemical weapons attack on civilians and a US special forces soldier was killed in Nangarhar Province. Perhaps President Trump was indicating a willingness to trust his commanders to make decisions like this, especially given President Obama's likely reluctance to allow MOAB use (Engel, 2017).

\section{Methodology: News Media and Social Media}

\section{News Coverage}

Lexis Uni, a database of global newspapers and broadcast transcripts, was used to pull news media output from April 12, 2017 through December 31, 2018. That period represents the day before the news broke about MOAB through the first anniversary and eight months past. The English language content selected came from different parts of the world and contained background information about the bomb and descriptions of the destruction it caused. Because of the large number of articles and transcripts produced, articles were selected based on their origin and uniqueness rather than as a result of a random selection.

To collect social media content, a monitor was set up on Crimson Hexagon (using the LSU Manship School of Mass Communication Social Media Analysis and Content Lab's license). Specific posts (from Tweets, Retweets, blogs, etc.) were pulled across social media and from multiple countries.

While the American military were clearly proud of the bomb and its performance and the American media were mostly neutral to dismissive, the European and Middle Eastern leaders and media were much more alarmed. Determining worldwide public opinion about the topic is considerably more difficult than analyzing news coverage. Social media posts about MOAB were collected through Crimson Hexagon beginning on April 12, 2017 and ending in January 2019. (Nearly all the comments were posted during the remainder of 2017 with concentration in April and May 2017.)

The software used algorithms to characterize the posts and analyze the posts' origins, authors and sources. Sentiments, emotions and limited demographics can be produced. Crimson Hexagon provided a "fuzzy" picture of public opinion, but it is the most efficient way to collect a large number of social media posts despite some limitations. During the time these statements were collected, bots were not well known or exposed. However, the sources of the statements are, for the most part, legitimate sources as shown below.

To make Crimson Hexagon efficient, key words or phrases are set to select the content. In this case, "MOAB," "bomb," "Mother of all Bombs," "Afghanistan," and "Trump" were used to set up the monitor. Crimson Hexagon provided various descriptions of the statements including country of origin, most prolific authors and sentiment. Social media largely mirrored the news media in that MOAB was a topic for a short period of time. 
A total of 64,737 posts were collect between April 12, 2017, and December 31, 2018. However, posts peaked at 46,648 on April 13 and mostly disappeared after April 24, 2017. The daily volume dwindled to five or less from then on, even on the first anniversary.

Twitter accounted for 88 percent of the posts. Forums accounted for 8 percent, and blogs accounted for 4 percent. Facebook, Reddit and comments accounted for less than 1 percent each.

A word cloud was produced to see the relationship among the key words. (See Appendix B.) Eighty-three percent of the posts used neutral language, 2 percent were rated as positive, while 15 percent were rated as negative. The overwhelming emotion expressed was fear (84 percent). Other emotions expressed included sadness ( 7 percent), disgust ( 5 percent), joy ( 3 percent) and surprise (1 percent). (See Appendix C.)

The United States contributed 61 percent of the posts, the most of any country. The next top countries were India (6.5 percent), United Kingdom (5.3 percent), Canada (2.5 percent) and Pakistan (2.2 percent). In all, 100 countries were represented. (See Appendix D.)

\section{Findings}

Although concern about MOAB appeared fleeting on social media and in the American news media, other adversarial government were paying attention and took the opportunity to flex some weapons muscles of their own. The top social media hosts were mostly American with insiders.foxnews.com leading the way, followed closely by apnews.com and www.cnn.com. Among the top 16 hosts are also sputniknews.com, indiatoday.intoday.in and www.independent.co.uk (Table 1).

Twitter was by far the most the top social media site with 88 percent of the captured posts originating there. Defence.pk was the only international source to be among the top five sources (Table 2).

Posts originating from CNN were the most retweeted, with Fox News as a distant second. Among the top 10 sources, two individuals appeared in the list of mostly news organizations: Piers Morgan and Brian Fraser (Table 3).

Popular hashtags focused on Afghanistan and MOAB, but \#MAGA (Make America Great Again) was also among the top 10 (Table 4). 
Table 1. The Top 16 Social Media Hosts

\begin{tabular}{|l|c|}
\hline Site & Total Posts \\
\hline insider.foxnews.com & 504 \\
\hline apnews.com & 491 \\
\hline www.cnn.com & 490 \\
\hline www.newyorker.com & 235 \\
\hline sputniknews.com & 157 \\
\hline www.nytimes.com & 143 \\
\hline edition.cnn.com & 137 \\
\hline abcnews.go.com & 132 \\
\hline consumercounseling.org & 123 \\
\hline twitter.com & 116 \\
\hline www.businessinsider.com & 109 \\
\hline abc7.com & 96 \\
\hline indiatoday.intoday.in & 89 \\
\hline nypost.com & 88 \\
\hline boingboing.net & 87 \\
\hline www.independent.co.uk & 81 \\
\hline
\end{tabular}

Table 2. The Top Five Social Media Sites

\begin{tabular}{|l|c|c|}
\hline Social Media & Number & Percent \\
\hline twitter.com & 56,743 & $88 \%$ \\
\hline blogspot.com & 693 & $1 \%$ \\
\hline facebook.com & 485 & $<1 \%$ \\
\hline defence.pk & 387 & $<1 \%$ \\
\hline usmessageboard.com & 247 & $<1 \%$ \\
\hline
\end{tabular}

Table 3. The Top Ten Social Media Authors that Were Re-Tweeted

\begin{tabular}{|l|l|}
\hline Occurrences & Original Author \\
\hline 17,000 & CNN (CNN) \\
\hline 5,400 & FoxNews (Fox News) \\
\hline 8400 & piersmorgan (Piers Morgan) \\
\hline 700 & bfraser747 (BRIAN FRASER) \\
\hline 650 & FoxNews (Fox News) \\
\hline 590 & Complex (Complex) \\
\hline 550 & FoxBusiness (FOX Business) \\
\hline 400 & ajplus (AJ+) \\
\hline 370 & AP (The Associated Press) \\
\hline
\end{tabular}

Note: Examples of the types of social media posts Crimson Hexagon collected are found in Appendix E. 
Table 4. Top Ten Hashtags

\begin{tabular}{|l|c|}
\hline Hashtags & Number \\
\hline \#Afghanistan & 3,900 \\
\hline \#MOAB & 2,500 \\
\hline \#BreakingNews & 870 \\
\hline \#ISIS & 820 \\
\hline \#Trump & 710 \\
\hline \#BREAKING & 620 \\
\hline \#MAGA & 360 \\
\hline \#MOAB- & 300 \\
\hline \#BoomShakaLaka & 290 \\
\hline \#DC & 260 \\
\hline
\end{tabular}

Although no mega bombs have been used to date (September 2019), threats and weapons testing has occurred. The countries that reacted on social media provide insights into which countries were paying attention. India and Pakistan, in continuous conflict over Cashmere, were among the top posters on social media. Members of the European Union and the British Commonwealth - members of NATO - were also paying attention. Although the Afghan military was involved in the planning to drop MOAB, NATO commanders apparently were not in the decision loop. South Korea and Japan, the two countries that are under the most threat from North Korean missiles, also were among the top social media posters. Nigeria and South Africa, as well as Mexico and key Central and South America countries also had posters who expressed concern. The American news media initially offered the most basic information about MOAB, providing the history of the bomb's development but the reports lacked details about its destructive power. In fact, very little American coverage of the Afghan war was happening before MOAB was dropped. All media were too absorbed in President Trump's first 100 days, the traditional period to evaluate a new president's "honeymoon period" accomplishments, to allocate resources to foreign affairs. After MOAB was dropped, the American news media were more likely than foreign media to report support for the deployment.

European and Middle Eastern media, on the other hand, provided more graphic details about MOAB's deployment and the aftermath. They also were more mixed in reports of support and opposition to using the bomb. One of the immediate concerns after news spread about the MOAB deployment was whether a new arms race would ensue. Rather than having fears only about nuclear proliferation, critics now were concerned about mega smart bomb proliferation. Recent evidence exists that such fears are warranted. The DoD has admitted that MOAB has competition. On September 11, 2007, the Russian military announced it had tested the "Father of all Bombs," the world's most powerful non-nuclear air-delivered munition. According to the DoD and globalsecurity.org, "The Russians claim it is four times more powerful than the MOAB, even thought it technically has fewer explosive in it (7.8 tons compared with the MOAB's 8 tons). The FOAB is said to use more efficient explosives, yielding the equivalent of 44 tons of TNT with a blast radius of 300 meters - double that of the MOAB (Collins, 2017)." 
As of early January 2018, China entered the fray. Using social media, the official Xinhua news agency described its bomb, calling it the "Chinese version of the 'Mother of all Bombs'." It was dropped by a Chinese $\mathrm{H}-6 \mathrm{~K}$ bomber. The Chinese bomb was between 16 and 20 feet but weighs less than the American version. Still military analyst Wei Dongxu reportedly claimed that the explosion produced would easily wipe out land fortifications ("China tests," 2019).

In a 2017 article in The Defence Journal, Taiqeer Jissaom Sargama painted a bleak picture of the current state of world armaments. He posited that post 9/11 the United State not only "overstretched its military muscles" but also "introduced aggression in its foreign policy." Introducing MOAB in the US conventional military strategy has ushered in a new era of military confrontation among traditional Cold War competitors. At the top of this new food chain are the United States, the Russians and the Chinese, all of whom have developed powerful nonnuclear bombs. The next tier is comprised of Israel, Iran, India and Pakistan. Further, Sargama predicts that these seven "players" will not be in isolation but rather will form alliances of the United States and Israel, Russia and Iran, with China and Pakistan the most likely to woo India (Sargana, 2017).

February and March 2019 have shown additional signs that weapon deployment have increased. A suicide bombing in Pulwama, Kashmir in February left 40 Indian paramilitary personnel dead and stirred long-standing tensions between India and Pakistan. The Indian Air Force launched a retaliatory strike against a terrorist training camp in Balakot. Pakistan responded with a strike; and in a subsequent dogfight, an Indian aircraft was shot down and the pilot was captured. Tensions eased somewhat when the pilot was released. Both India and Pakistan have nuclear weapons (Rao, 2019).

In March two rockets reached Tel Aviv for the first time since 2014. The New York Times reported that the rockets were fired from the Gaza Strip, and Israel blamed Hamas, the Islamic militant group that controls Gaza, although Israeli military officials said the rockets were launched "by mistake" (Halbfinger, 2019). On the other hand, Al Jazeera's English language website, reported the story somewhat differently. Israel, Al Jazeera said, launched air attacks on Gaza after rockets were "allegedly fired near Tel Aviv" and that the Israeli military had claimed in a Twitter post that 100 Hamas targets in Gaza were hit (Al Jazeera, 2019). The area of agreement between the two sources was that tensions are escalating once again.

The failed second summit between President Trump and North Korea's Kim Jong-un on February 27-28, 2019, also signaled a dangerous escalation involving the United States, South Korea and Japan. The Guardian reported that the two sides disagreed as to why the summit failed. President Trump said that North Korea wanted sanctions lifted without a complete denuclearization, while North Korean foreign minister, Ri Yong Ho, said Pyongyang had only demanded partial sanctions relief in return for closing Yongbyon, the major nuclear facility. He said the United States had "wasted an opportunity that 'may not come again'" and Pyongyang's position would not change (Borger, 2019). In March North Korea threatened to break off further negotiations with the United States and resume missile and nuclear testing (Paris, 2019). Further, CNN reported that 
satellite images appear to show that North Korea has begun rebuilding a portion of a facility previously used to test long-range missile engines even though President Trump has said the United States and South Korea would not resume joint military operations (Berlinger, 2019).

Following the Trump administration's announcement in May 2019 that the United States would sell weapons to Saudi Arabia, the United Arab Emirates and Jordan as well as deploying about 1,500 additional troops to the Middle East to challenge Iran, the rhetoric escalated to a new degree. Iranian Gen. Moreza Qorbani threatened the 10 US ships that had already deployed to the Mediterranean, saying, "If they commit the slightest stupidity, we will send these ships to the bottom of the sea along with their crew and planes using two missiles or two new secret weapons" (Karasz, 2019).

President Trump seemed at odds with his former national security adviser, John R. Bolton, label by many US media as a "hard-liner" or "hawk" who wants a regime change in Iran. President Trump pulled out of the Obama-era agreement with Iran to restrict nuclear weapon development in May 2018 because he did not think the agreement was strong enough. While visiting Japanese Prime Minster Shinzo Abe on May 27, 2019, Trump insisted, "We're not looking for regime change. I want to make that clear. We're looking for no nuclear weapons" (Kranish, 2019).

\section{Discussion}

The United States' deployment of MOAB never reached the level of concern that dropping the nuclear bombs Fat Man and Little Boy on Hiroshima and Nagasaki produced. Perhaps labeling it as non-nuclear dispelled long-lasting fear. MOAB also was perhaps the perfect weapon for the Afghanistan caves and tunnels that were shielding soldiers who were label as terrorists. The concussive nature of MOAB also worked more efficiently than traditional bombs to collapse the tunnels and kill the enemy without endangering American and Afghan soldiers.

Either the US military kept MOAB's transfer to Afghanistan a secret or journalists who cover the military agreed not to report it. No hints surfaced that the bomb might be used in Afghanistan for either political or military purposes.

Perhaps the most important part of the story is that no civilian casualties were reported from the action. If this is true, it likely was because the villagers in the area were warned repeatedly to leave. A few civilians who remained obviously did see the building damage that was done - but apparently news agencies and Afghan government officials were denied access to the area, limiting damage and civilian casualty assessments.

The American media covered the bombing but gave few details as to the aftermath. Gone are the days when American media have bureaus spread around the world - particularly in the Middle East - to provide ongoing, in depth reporting. The cost has become prohibitive as media revenues declined and as protecting journalists from kidnappers and combat situations became more difficult and expensive. 
The American media have also been completely absorbed with the Trump presidency and the investigations into Russian interference in the 2016 election. Perhaps because President Trump has not mentioned MOAB since the bombing and did not take credit for dropping it, the media stopped paying attention. Did the president authorize the bomb, or did he see how to capitalize on it to deliberately threaten North Korea? Iran? Russia? China? Why then, has he said he is pulling troops out of Syria and hinted at also abandoning Afghanistan? Is he oblivious to the new arms race that has begun? Or, has he talked with Vladimir Putin and Xi Jinping about it?

The European and Middle Eastern media are not oblivious. But, although they did a much more in-depth job of covering the bombing, the event has largely faded without tracing links to the many renewed conflicts in various parts of the world. They have done a better job than the American media of reporting on the Russian and Chinese bombs and have been more aware of the changes in the American foreign policy than domestic media appear to be.

\section{Conclusion}

The void in coverage has left many unanswered questions. The speculation is that the United States has at least 20 MOABs in its arsenal, but no official number has been reported. Neither do we know whether MOABS are in the Middle East with US troops. The Nation reported on February 6, 2018, that the United States has eclipsed the GBU-43/B with an even larger non-nuclear weapon, the 30,000-pound GBU-57 Massive Ordnance Penetrator (MOP), dubbed by some the "father of all bombs" to distinguish it from the MOAB. The publication reported (without an identified source) that the FOAB was first prepared to bomb Iranian nuclear facilities but that it now was to be available to prevent North Korea from creating an intercontinental ballistic missile (ICBM) capable of delivering nuclear warheads to the continental United States (Klare, 2018). Was it a bluff or did the military intend to use it? Did it cause Kim Jong-un to stop the development of his delivery system or even of his nuclear weapons? North Korea's threat to the United States largely faded from the news until the failed Vietnam summit between the two leaders. Has the adversarial relationship eased or is this just the lull before a much bigger and deadlier confrontation?

Leaders in Europe, Asia and the Middle East know this is not the true end of this story. They remember, if the US media do not, that the United States to date is the only country in the world to deploy both nuclear bombs and MOAB. 


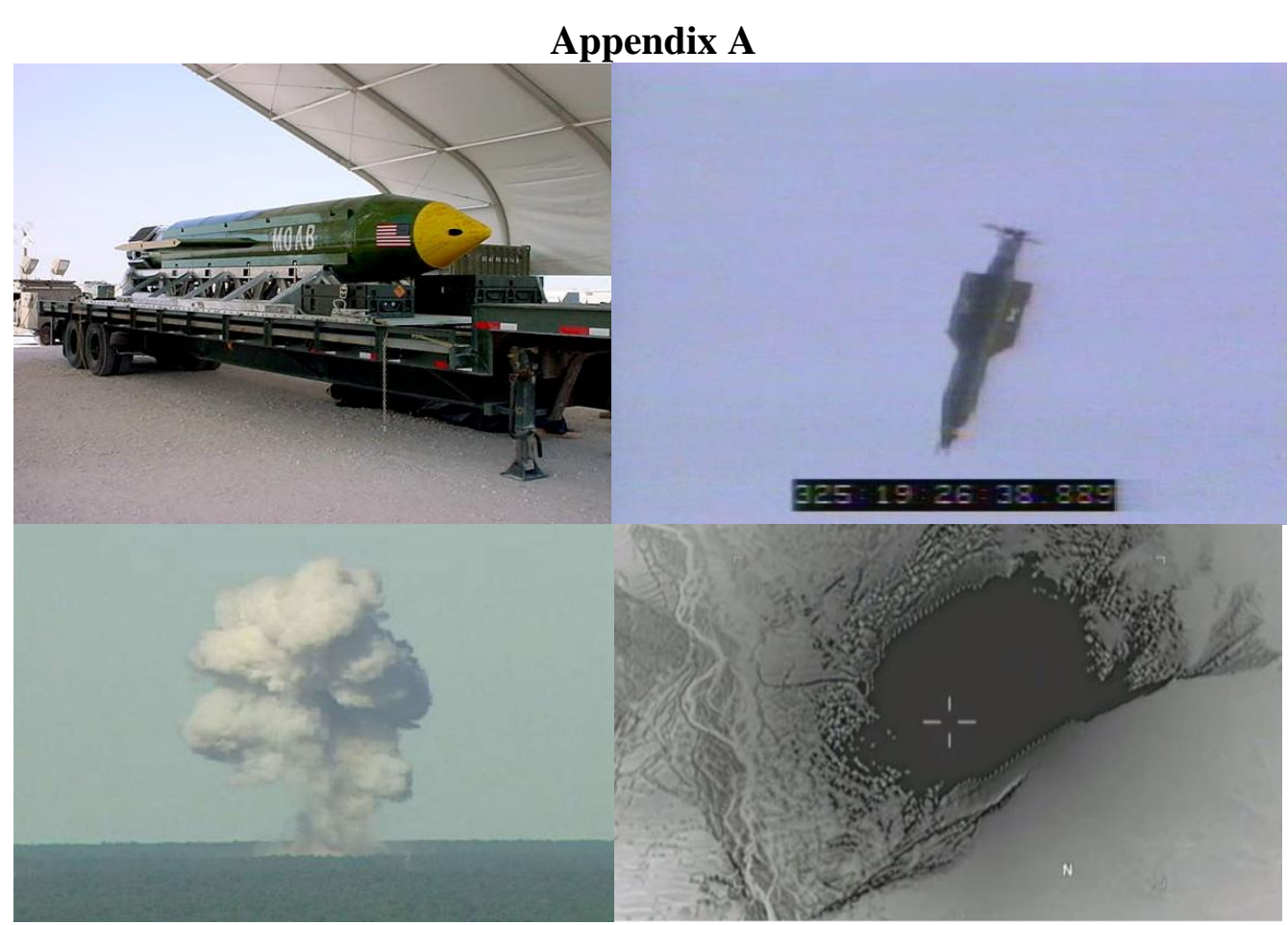

Source: Department of Defense.

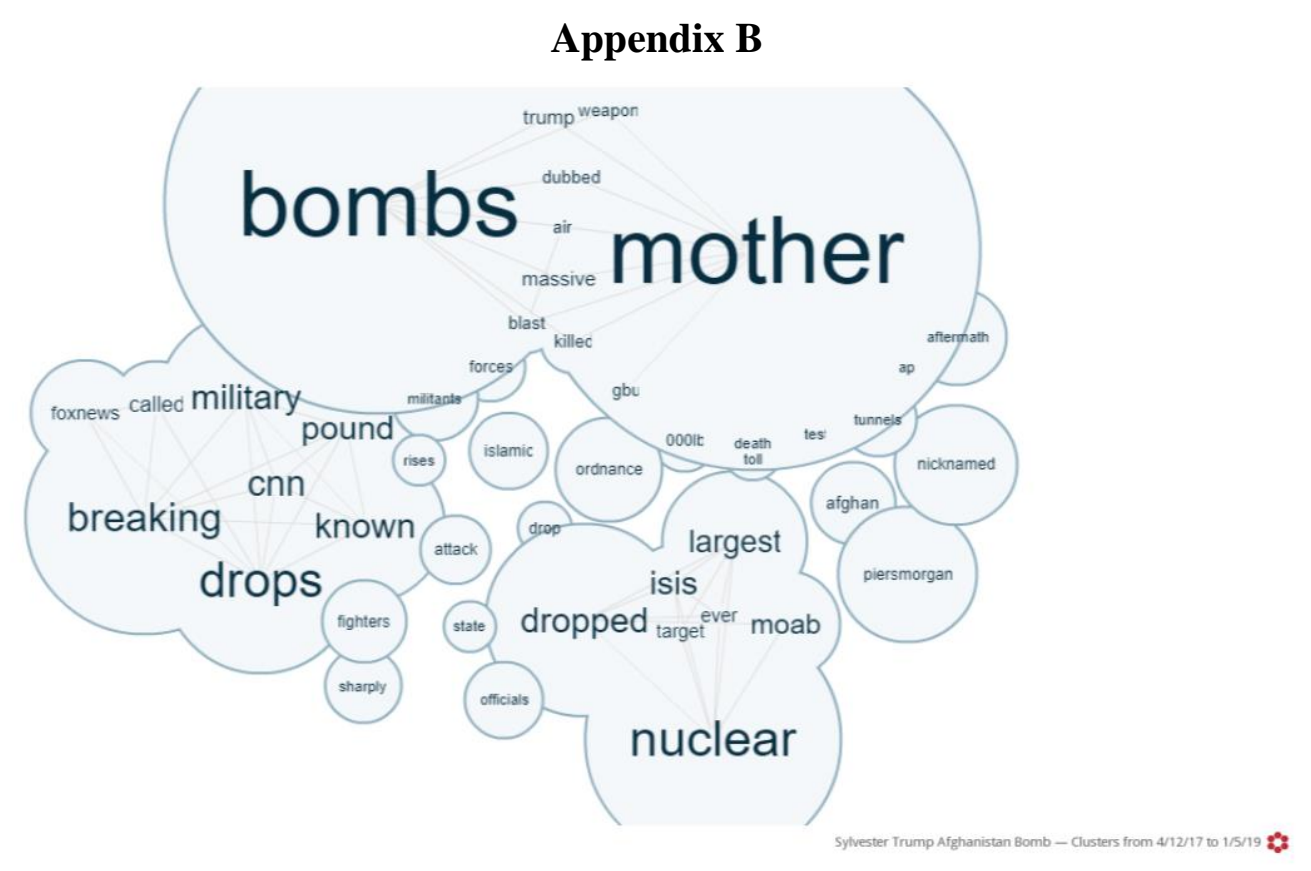


Appendix C

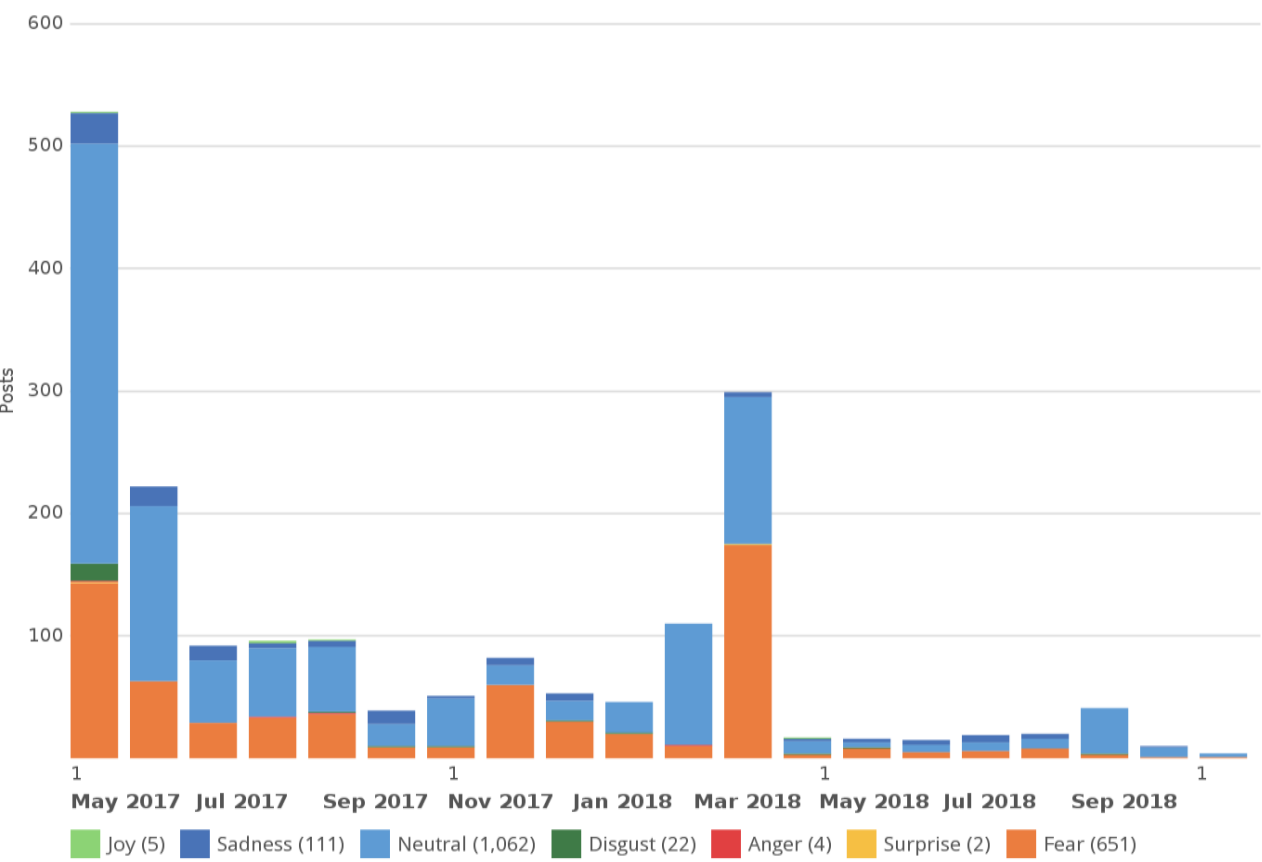

Sylvester Trump Afghanistan Bomb - Volume of Posts (Emotion) from 4/12/17 to 1/5/19 


\section{Appendix D}

\section{\# $\quad$ Country}

1 United States of America

2

3

4
5

6

$$
7
$$$$
8
$$$$
9
$$

India

United Kingdom

Canada

Pakistan

Nigeria

Indonesia

Japan

Brazil

Mexico

South Africa

Australia

Thailand

South Korea

Spain

France

Kenya

Singapore

Germany

Malaysia

Sweden

Netherlands

Philippines

Russia

Italy

Ireland

Venezuela

Chile

Colombia

Saudi Arabia

Argentina

Turkey

Afghanistan

Belgium

United Arab Emirates

Ghana

China

Puerto Rico

Egypt

Jamaica

Vietnam

Ukraine

Ecuador

Israel

Austria

Portugal

Norway

Republic of Serbia

Panama

\section{Posts}

27140

2901

2367

1090

959

651

580

491

451

415

399

389

387

382

365

292

289

256

254

228

211

202

188

173

164

156

146

130

122

121

110

107

105

103

99

80

77

76

74

65

63

54

52

50

49

48

48

46

45
$\%$ of total

$61.22 \%$

$6.54 \%$

$5.34 \%$

$2.46 \%$

$2.16 \%$

$1.47 \%$

$1.31 \%$

$1.11 \%$

$1.02 \%$

$0.94 \%$

$0.90 \%$

$0.88 \%$

$0.87 \%$

$0.86 \%$

$0.82 \%$

$0.66 \%$

$0.65 \%$

$0.58 \%$

$0.57 \%$

$0.51 \%$

$0.48 \%$

$0.46 \%$

$0.42 \%$

$0.39 \%$

$0.37 \%$

$0.35 \%$

$0.33 \%$

$0.29 \%$

$0.28 \%$

$0.27 \%$

$0.25 \%$

$0.24 \%$

$0.24 \%$

$0.23 \%$

$0.22 \%$

$0.18 \%$

$0.17 \%$

$0.17 \%$

$0.17 \%$

$0.15 \%$

$0.14 \%$

$0.12 \%$

$0.12 \%$

$0.11 \%$

$0.11 \%$

$0.11 \%$

$0.11 \%$

$0.10 \%$

$0.10 \%$ 


\begin{tabular}{|c|c|c|c|}
\hline 50 & New Zealand & 43 & $0.10 \%$ \\
\hline 51 & Switzerland & 39 & $0.09 \%$ \\
\hline 52 & Peru & 39 & $0.09 \%$ \\
\hline 53 & Costa Rica & 37 & $0.08 \%$ \\
\hline 54 & Trinidad and Tobago & 32 & $0.07 \%$ \\
\hline 55 & Denmark & 31 & $0.07 \%$ \\
\hline 56 & Lebanon & 30 & $0.07 \%$ \\
\hline 57 & Dominican Republic & 29 & $0.07 \%$ \\
\hline 58 & Hong Kong S.A.R. & 29 & $0.07 \%$ \\
\hline 59 & Sri Lanka & 27 & $0.06 \%$ \\
\hline 60 & Czech Republic & 27 & $0.06 \%$ \\
\hline 61 & Maldives & 27 & $0.06 \%$ \\
\hline 62 & Zimbabwe & 24 & $0.05 \%$ \\
\hline 63 & Nepal & 24 & $0.05 \%$ \\
\hline 64 & Guatemala & 24 & $0.05 \%$ \\
\hline 65 & Uganda & 24 & $0.05 \%$ \\
\hline 66 & Finland & 23 & $0.05 \%$ \\
\hline 67 & Poland & 22 & $0.05 \%$ \\
\hline 68 & United Republic of Tanzania & 22 & $0.05 \%$ \\
\hline 69 & Paraguay & 22 & $0.05 \%$ \\
\hline 70 & Greece & 20 & $0.05 \%$ \\
\hline 71 & El Salvador & 19 & $0.04 \%$ \\
\hline 72 & Romania & 18 & $0.04 \%$ \\
\hline 73 & Mongolia & 17 & $0.04 \%$ \\
\hline 74 & Hungary & 17 & $0.04 \%$ \\
\hline 75 & Iran & 16 & $0.04 \%$ \\
\hline 76 & Kuwait & 16 & $0.04 \%$ \\
\hline 77 & Jordan & 16 & $0.04 \%$ \\
\hline 78 & Qatar & 15 & $0.03 \%$ \\
\hline 79 & Barbados & 15 & $0.03 \%$ \\
\hline 80 & Iraq & 13 & $0.03 \%$ \\
\hline 81 & Somalia & 13 & $0.03 \%$ \\
\hline 82 & Palestine & 12 & $0.03 \%$ \\
\hline 83 & Azerbaijan & 12 & $0.03 \%$ \\
\hline 84 & Latvia & 12 & $0.03 \%$ \\
\hline 85 & Uruguay & 11 & $0.02 \%$ \\
\hline 86 & Saint Lucia & 11 & $0.02 \%$ \\
\hline 87 & Yemen & 10 & $0.02 \%$ \\
\hline 88 & Malawi & 10 & $0.02 \%$ \\
\hline 89 & Iceland & 9 & $0.02 \%$ \\
\hline 90 & Syria & 9 & $0.02 \%$ \\
\hline 91 & The Bahamas & 9 & $0.02 \%$ \\
\hline 92 & Bahrain & 8 & $0.02 \%$ \\
\hline 93 & Tuvalu & 8 & $0.02 \%$ \\
\hline 94 & Honduras & 8 & $0.02 \%$ \\
\hline 95 & Botswana & 7 & $0.02 \%$ \\
\hline 96 & Bangladesh & 7 & $0.02 \%$ \\
\hline 97 & Myanmar & 6 & $0.01 \%$ \\
\hline 98 & Isle of Man & 6 & $0.01 \%$ \\
\hline 99 & Malta & 5 & $0.01 \%$ \\
\hline 100 & Montenegro & 5 & $0.01 \%$ \\
\hline
\end{tabular}




\section{Appendix E}

(Examples of Crimson Hexagon Comments)

RT @Complex U.S. military drops 21,600 pound bomb — known as the "mother of all bombs"—in Afghanistan: https://t.co/hVRwqoNNgz https://t.co/BmVFZ3870P

RT @CNN BREAKING: US military drops 21,000-pound non-nuclear bomb -- known as the "mother of all bombs" — in Afghanistan https://t.co/EOji2tjxzi https://t.co/VlQNjTRnqa

Another Promise Kept: Trump 'Bombs the Sh*t' Out of ISIS - Drops 'Mother of All Bombs' on ISIS in Afghanistan https://t.co/x9Ad6SOS8o

RT @CNN BREAKING: US military drops 21,000-pound non-nuclear bomb -- known as the "mother of all bombs" — in Afghanistan https://t.co/EOji2tjxzi https://t.co/VlQNjTRnqa

RT @foxnewsalert 'MOTHER OF ALL BOMBS': US drops massive bomb in Afghanistan https://t.co/ZCwe3oy1mG

RT @CNN BREAKING: US military drops 21,000-pound non-nuclear bomb -- known as the "mother of all bombs" — in Afghanistan https://t.co/EOji2tjxzi https://t.co/VlQNjTRnqa

RT@FrancoandMarco The Mother of all Bombs. The perfect distraction from Chump's endless media embarrassments. Bomb an insignificant target in Afghanistan https://t.co/ LpNZBe9tuz

RT @LawyerRogelio WTF R WE GOING 2 BOMB OUR WAY? US drops 'mother of all bombs' in Afghanistan, largest non-nuclear weapon - https://t.co/6aCAl0DcBc via @ ABC

http://www.independent.co.uk/news/world/americas/gbu-43b-mother-of-all-bombsmassive-ordnance-air-blast-afghanistan-isis-a7682996.html Quote: The US has dropped the largest non-nuclear bomb in the countrys arsenal on an area of eastern Afghanistan known to be populated by Islamic State militants. The Pentagon said the strike was the first time the 21,000lb weapon had been used in combat operations. A spokesperson for the US Department of Defence confirmed to The Independent that a MC-130 aircraft dropped a GBU-43 bomb at 7pm local time. The weapon is known in the US Air Force by its nickname MOAB, or "mother of all bombs". MOAB stands for massive ordinance air blast. ====================::=================== Normally I am against bombing other countries, though I make an exception for ISIS. I've heard tragically little up until now about ISIS setting up operations in Afghanistan, though.

RT @bfraser747 $\square \square \square$ BREAKING N WS "U.S. drops largest non-nuclear bomb in Afghanistan; called "mother of all bombs" VIA @FoxNews https:/ t.co/lbs NIte09 https://t.co/APriBhYrJc

Afghanistan: US defends dropping 'mother of all bombs' \#CongressionalAppr val? \#Trumpinator @HRH_Sir_Loin https://t.co/ls7AhvF6GM

RT @AP Death toll in Afghanistan from "mother of all bombs" rises sharply. https://t.co/lKFYII3oFU

36 ISIS fighters killed by US 'mother of all bombs' https://t.co/byywmNCQvi

RT @ piersmorgan BREAKING: US just dropped largest ever non-nuclear bomb on ISIS target in Afghanistan. A 21,000lb weapon dubbed 'Mother of all Bombs' - CNN.

Mother Of All Bombs- US Drops Largest Non-Nuclear Bomb In Afghanistan YouTube https://t.co/BB05683Sqb

'Right weapon for right target': Top US commander defends use of 'mother of all bombs' https://t.co/Cgue1e7zfJ

RT @BNONews U.S. DROPS MASSIVE BOMB - Target: ISIS tunnel complex Eastern Afghanistan - GBU-43 bomb (11 tons TNT) - AKA: MOAB/Mother of all 
Bombs

RT @CNN BREAKING: US military drops 21,000-pound non-nuclear bomb -- known as the "mother of all bombs" — in Afghanistan https://t.co/EOji2tjxzi https://t.co/VlQNjTRnqa

RT @CNN BREAKING: US military drops 21,000-pound non-nuclear bomb -- known as the "mother of all bombs" — in Afghanistan https://t.co/EOji2tjxzi https://t.co/VlQNjTRnqa

RT @RT_com Internet erupts as Trump drops 21,000-pounds 'Mother of All Bombs' on \#Afghanistan https://t.co/8BLNu7FN3r \#MOABBomb https://t.co/EOtC02pgAG

"We have been waiting months to use it," said an official in Afghanistan on the use of the "Mother of All Bombs" https://t.co/r0v1H33xiP

RT @ AdityaRajKaul \#BREAKING: US drops largest non-nuclear GBU-43/B Massive Ordnance Air Blast Bomb (mother of all bombs) on \#ISIS hideout in \#Afghanistan.

RT @CNN BREAKING: US military drops 21,000-pound non-nuclear bomb -- known as the "mother of all bombs" — in Afghanistan https://t.co/EOji2tjxzi https://t.co/VlQNjTRnqa 


\section{References}

Abadi, M. (2017, April 13). The phrase "mother of all bombs" has a long history in the Middle Ease. The Business Insider. Retrieved from https://ces.to/H7zqK, Nexis Uni.

Al Jazeera. (2019, March 15). Israel launches Gaza air attacks after rockets fired at Tel Aviv. Retrieved from https://ces.to/jBMxuK.

Berlinger, J. (2019, March 6). Satellite images show activity at North Korean missile site, analysts say. Retrieved from https://ces.to/OPPFBG.

Borger, J. (2019, March 1). Vietnam summit: North Korea and US offer differing reasons for failure of talks. Retrieved from https://ces.to/LqFud7.

Burns, R. (2017, April 14). Officials: No need for Trump's approval to use massive bomb. Associated Press. Retrieved from https://ces.to/s7Lffz.

CBS Interactive, Inc. (2017, April 4). US drops "mother of all bombs" in Afghanistan, marking weapon's first use. Retrieved from https://ces.to/M53Gdo.

China tests its own "Mother of All Bombs". (2019, January 4). Tribune.com. Retrieved from https://ces.to/LZY0kQ, Nexis Uni.

Collins, S. (2017, April 14). What to Know About the GBU-43/B, "Mother of All Bombs". DoD News, Defense Media Activity. Washington, D.C.: US Department of Defense.

Cooper, H., and Marshal, M. (2017, April 13). US Drops "Mother of All Bombs" on ISIS Caves in Afghanistan. New York Times. Retrieved from https://ces.to/67Jh0O.

Corera, G. (2011, July 21). Bin Laden's Tora Bora escape, just months after 9/11. BBC News. Retrieved from https://ces.to/7ogvpE.

DAILYMAIL.COM REPORTER. (2017, April 14). How the Mother of All Bombs kills people. Daily Mail. Retrieved from https://ces.to/YzH3fN.

Downie, J. (2016, May 5). Obama's drone war is a shameful part of his legacy. The Washington Post. Retrieved from https://ces.to/DGMvhN.

Engel, P. (2017, April 14). Spicer on dropping "mother of all bombs": The US "takes the fight against ISIS very seriously". The Business Insider. Retrieved from https://ces.to/Vx1YIO, Nexis Uni.

Gabriel, M. N. (2017, April 13). "Mother of All Bombs" was developed at Florida base. Retrieved from https://ces.to/5yqNN3.

Hains, T. (2017, April 13). Trump on MOAB: I've Given The Military "Total Authorization," "That's Why They've Been So Successful Lately." Real Clear Politics. Retrieved from https://ces.to/6ZtHUr.

Halbfinger, D. M. (2019, March 14). Rockets Fired on Tel Aviv; Israel Retaliates With Strikes on Gaza. New York Times, p. A7. Retrieved from https://ces.to/Np4Q0I.

Hamdard, A. (2017, April 17) MOAB attack was a right action, says Abdullah. Pajhwok Afghan News English. Retrieved from https://ces.to/YhyU2r, Nexis Uni.

Karasz, P. (2019, March 14). Iran Slams US After Middle East Troop Buildup Is Announced. New York Times. Retrieved from https://ces.to/M2zO1c.

Kranish, M. ((2019, May 27). Trump says he is not seeking "regime change" in Iran. Washington Post. Retrieved from https://ces.to/QzFPLg.

Klare, M. T. (2018). Pentagon Readies the "Father of All Bombs" for Use Against North Korea. TheNation.com. Retrieved from https://ces.to/6uVhcb.

Latifi, A. M. (2017, April 20). Mother of All Bombs. New York Times International Edition, pp. Op-Ed. Retrieved from https://ces.to/YUyUld.

McLaughlin, K. (2017, April 20). Afghan tribal leaders praise US for "Mother of all bombs" strike, saying it has "pulled ISIS out by the roots from the region" and 
"finished off a huge threat to our people". Dailymail.co.uk. Retrieved from https://ces.to/yMR8in, Nexis Uni.

Paris, F. (2019, March 15). N. Korea Considering Whether to Resume Nuclear, Missile Tests Amid Impasse With US. Retrieved from https://ces.to/ipUEd8.

Rao, N. (2019, March 11). How India and Pakistan can step back from the brink of war. Washington Post, p. Global Opinion.

Rasmussen, S. E. (2017, April 14). "It felt like the heavens were falling": Afghans reel from Moab impact. Theguardian.com. Retrieved from https://ces.to/GnhHcs, Nexis Uni.

Robinson, J. (2017, April 17). Former Afghan president Hamid Karzai accuses the US of using his country as a weapons testing ground as he blasts "atrocity" of Mother of All Bombs strike. MailOnline. Retrieved from https://ces.to/q0baI1.

Sargana, T. H. (2017, May 21). The American MOAB vs. Russian FOAB. Defence Journal, 20(10).

Silverstein, J., \& Dillon, N. (2017, April 14). ISIS, HAVE A BLAST! US biggest nonnuke hits Afghanistan Bomb made in '03, but not used before. Daily News (New York), NEWS, 6.

Szoldra, P. (2017, April 14). Fox News host says dropping "mother of all bombs" on ISIS is "what freedom looks like". Businessinsider.com. Retrieved from https://ces.to/jlmzzI.

Team. (2008, December 31). Eglin AFB Public Affairs. 'Doc' Register to be honored with building dedication. Florida: Eglin Air Force Base. Retrieved from https://ces.to/97 AB8f.

The Associated Press. (2017, April 15). Approval not needed to use massive bomb. Retrieved from https://ces.to/iK9DaB.

Young, G. (2017, April 13). Expert: 'MOAB' Drop Location Should Not Affect Civilians. Targeted News Service. Retrieved from https://ces.to/IumwUA.

Zachary, S. (2008, March 11). "Mother of All Bombs" celebrates 5 years. Press Release. 96th Air Base, Florida: Eglin Air Force Base. Retrieved from https://ces.to/fmNkXo. 